This item was submitted to Loughborough's Research Repository by the author.

Items in Figshare are protected by copyright, with all rights reserved, unless otherwise indicated.

\title{
Extending the social psychology of racism : a framework for critical analysis
}

PLEASE CITE THE PUBLISHED VERSION

http://dx.doi.org/10.1093/oxfordhb/9780199938735.013.8

\section{PUBLISHER}

(c) Oxford University Press

\section{VERSION}

AM (Accepted Manuscript)

\section{PUBLISHER STATEMENT}

This work is made available according to the conditions of the Creative Commons Attribution-NonCommercialNoDerivatives 4.0 International (CC BY-NC-ND 4.0) licence. Full details of this licence are available at: https://creativecommons.org/licenses/by-nc-nd/4.0/

\section{LICENCE}

CC BY-NC-ND 4.0

\section{REPOSITORY RECORD}

Tileaga, Cristian. 2019. "Extending the Social Psychology of Racism : A Framework for Critical Analysis". figshare. https://hdl.handle.net/2134/18135. 


\title{
Extending the social psychology of racism and moral exclusion:
}

\author{
A framework for critical analysis
}

Cristian Tileagă

Discourse and Rhetoric Group

Social Sciences

Loughborough University

Chapter in Hammack, P. (ed) The Oxford Handbook of Social Psychology and Social Justice. Oxford University Press 
In his book Racism, the French anthropologist Albert Memmi sketches one of the classic social anthropological portraits of racism. In his portrait, two philosophies that underlie the creation and propagation of racism are fused.

The first philosophy is a universalist philosophy. For Memmi the narrow sense of racism that makes reference to biological difference should coexist, encompassed in "one common definition", with a broader sense of the term racism. This broader sense of the term is what Memmi describes as "heterophobia", the 'rejection of the other in the name of no matter what difference' (2000, p. 121). The term heterophobia is used to designate "the many configurations of fear, hate, and aggressiveness ... varieties of hostility and exclusion" (p. 118-119). Heterophobia is a universal feature of the human condition. Memmi's description of heterophobia resonates with what might be called the established attitude of social psychology of racism. According to this view, both subtle and blatant biases are considered universal features of the human condition (Allport, 1954; Fiske, 2002). As Allport put it, "whatever our values may be prejudice is a fact of mental organization and a mode of mental functioning" (1954, p. 4, emphasis in original). The roots of prejudice (authoritarianism, social dominance, intergroup anxiety, threat, and so on), are 'universals' that manifest themselves in every society (Sidanius \& Pratto, 1999; Stenner, 2005), reflect the internal organization of personality and psychological processes (Mondak, 2010; Mondak \& Halperin, 2008), and explain a vast variety of hostile, exclusionary, behaviours and practices.

The second philosophy is a relativist philosophy that emphasizes the nature of racism as socio-communicative product, and the role of (communal) thinking and argument. Racism is "both a discourse and an action. It is a 
discourse that prepares an action, and an action that legitimates itself through a discourse' (Memmi, 2000, p. 142). There are striking parallels between Memmi's ideas and the critical social psychology of racism. According to this position, racism cannot be simply inferred from the internal organization of universal mental processes. Racist discourse is argumentative discourse (Billig, 2002; Tileagă, 2005, 2006; van Dijk, 1987). Ideologies of racism find their home in the complex and fragmented organization of common-sense (Billig, 1996). For discursive psychologists language is central to racist and exclusionary practice (Tileagă, 2007) and shifts can be fluidly made between arguments of principle and practice, liberal and illiberal tropes, for potentially racist effect or to justify and legitimate inequality, unfair treatment and exclusion (Wetherell \& Potter, 1992). They have also shown how people may inoculate themselves against bias and disclaim prejudice, either by constructing their views as rationally arrived at (Edwards, 2003), or by finding reasons with a basis in the world rather than their own subjectivity (Augoustinos \& Every, 2010; Tileagă, 2005).

Memmi's universalist and relativist arguments blend two histories of prejudice. The first conceives of the prejudiced mind separate from history and social context; the second conceives of it as a product of social context and history (cf. Durrheim, 2014). A central concern of this chapter is to consider the value of researching racism as social and cultural creation by embracing a thirdway philosophy that can complement both universalist as well as relativist approaches by borrowing from kindred fields - a framework that I would like to call "critical analysis". In this context, I use the case of exclusionary practices against Roma in Europe to consider how one might start analyzing the mundane as well as the extreme manifestations of anti-Roma sentiment without 
attributing it solely to antipathy and hostility. The Roma embody the new face of marginality (and poverty) that occasions moral-political dilemmas, stirs deepseated passions and unsettles the conventional, democratic, negotiation of social problems.

I begin this chapter with an examination of how a move away from attitudinal negativity and antipathy might open a space for considering prejudice as harm inflicted by indignity. I then explore and outline the main tenets of critical analysis as an attempt to cast the intellectual net beyond the traditional boundaries of the discipline. I argue that critical analysis opens the way for a meaningful, and renewed social psychology of racism that can establish itself more as a sociology and anthropology, rather than a psychology, of modern democratic culture. This in line with furthering the project of social psychology, as 'anthropology of modern culture' (Moscovici, 1972).

In the remainder of the chapter I assesses the value and possibility of such a project by exploring tragic fate of the Roma minority in Western and Eastern Europe. I argue that contemporary European discourse on the Roma reflects a variety of exclusionary social and political practices deeply engrained in the symbolic, material and socio-structural texture of Europe's liberal democracies. These are practices that demean, delegitimize, dehumanize, and yet are not necessarily perceived as racist. The label 'European citizen' does not offer much protection to Roma of different nationalities attempting to settle in the Union according to 'freedom of movement' rules. Self-worth, dignity, which most of us take for granted is refused to Roma. Roma are not only actively degraded by European societies; they are also constantly reminded of their modified worth and degraded status. It is this constant reminder of altered worth and degraded 
status that assures, justifies and perpetuates their moral exclusion.

Finally, I argue that by engaging conceptually and methodologically with insights from sociology and anthropology social psychology of racism can foster and champion a new meta-theory of racism that define (and tackles) racism as social and cultural creation, and places it at the heart of socio-structural, symbolic, societal arrangements in liberal democracies. One important aspect of a move towards a more sociologically and anthropologically infused meta-theory is to be able to mount and sustain a critique of current exclusionary practices of liberal democracies. A genuine social psychology of social justice should strive to offer the grounds for systematic social and moral critique of societal arrangements that advance or stifle the extension of solidarity and sympathy to others.

\section{From antipathy to indignity}

The idea of prejudice as "negative evaluation" is, arguably, the most enduring, and dominant, insight in social psychology of racism and intergroup relations (Dixon \& Levine, 2012). Researching the psychological bases of making hostile generalizations about members of another group takes one back to one of the classics of the discipline, Allport's (1954) The Nature of Prejudice. Allport devoted himself to considering prejudice as natural human phenomenon, a byproduct of categorical, natural thinking. According to him "erroneous generalization and hostility - are natural and common capacities of the human mind" (p. 17). Allport's exegesis and research programs that sprung out of it (for illustrations and reviews, see Dovidio et al., 2005; Brown, 2010) have advanced and unpacked the significance of Allport's meta-theory - "thinking ill of others 
without sufficient warrant", the irrational, false, unjustified, negative, evaluation of others because of their social category or group membership.

According to Allport, "prejudice is something and does something. It is not the invention of liberals. Its importance in society merely adds urgency to what is in any case a basic psychological problem" (Allport, 1950, p. 6, emphasis in original). If prejudice is and does something, as Allport suggests, then it is perhaps insufficient to define and research it as negative attitude towards members of particular groups, as antipathy based upon "faulty and inflexible generalization" (Allport, 1954, p. 9). Allport's emphasis on prejudice as negative evaluation is being challenged and qualified by alternative meta-theories. Researchers are drawing attention to the role of both negative, as well as positive attitudes or feelings about a person or a particular group in the production and reproduction of prejudice. For instance research on gender discrimination and the notion of "ambivalent sexism" point to the role of favorable attitudes towards women that can reproduce women's subordination (Glick \& Fiske, 2001). Jackman has argued against the notion of irrational hostility by noting that processes such as "discrimination and violence are driven by self-interested, rational, political motives. The central motivator for dominant groups in unequal social relations is not hatred, but the desire to control." (2005, p. 89-90). In a similar vein, Dixon and Levine argue that racist language continues to offend without the presence of deliberate hatred. As they argue, "ideological process need not operate via the attribution of uniformly negative qualities to others. Nor, indeed, is it necessarily accompanied by expressions of unadulterated hostility" (Dixon \& Levine, 2012, p. 311).

Other researchers have replaced Allport's negative evaluation meta-theory with 
a new meta-theory based on the importance of group membership. According to this view, "prejudice is bound up with the dynamics of ongoing intergroup relations, and the way that people make sense of these relations and form a shared collective view of their social world" (Reynolds et al. 2012, p. 49-50). Another important shift away from Allport's ontology was marked by approaches to prejudiced cognition that aim to restore "agency and sociality to the prejudiced subject" (Durrheim, 2012, p. 196). The various attempts to research "prejudice in the wild" through the perspective of distributed or collaborative cognition (e.g., Condor \& Figgou, 2012) have documented the subtle role that social interactions play in the expression of various forms of prejudice. In everyday conversations, prejudices "are gestured in forms of expression in which they are simultaneously revealed and hidden" (Durrheim, 2012, p. 194). Discursive psychologists have also moved away from Allport's emphasis on categorization and inner cognitive processes by emphasizing the role of discourse in the reproduction of racism (Wetherell \& Potter, 1992; Tileagă, 2005).

The idea that prejudice is not limited to negative evaluation nor experienced in a social vacuum is part of social psychology's canon. Yet there is one aspect that is missing even from more social, more encompassing, definitions of prejudice - the idea that prejudice can also be experienced as harm inflicted by indignity. Allport was certainly aware of this. Paradoxically, one has to return to Allport to find the simplest but also the most powerful social definition of discrimination - any behaviour that denies "individuals or groups of people equality of treatment which they may wish" (Allport, 1954, p. 51).

This is a definition that alludes to a dimension of aspirational worth, and 
dignity in social relations. According to Allport, discrimination is the resulting inequality based on differences of esteem (and respect). It is, paradoxically, more a sociological rather than a psychological definition of discrimination. Discrimination is wrong because it stifles public recognition of someone's social worth. When Allport writes about aspirational worth he brings into view people's rights to self-determination, self-definition, and moral inclusion into a moral community. Allport's definition points to a fundamental human motivation of striving for equality of worth, respect, esteem, moral inclusion.

Whether we are looking at gender, race, ethnicity, direct or subtle refusal of equality of treatment can have pernicious, direct or subtle, consequences leading to indignity. Again, it was Allport himself that recognized that prejudices are a "prime source of suffering and disvalue" (Allport, 1960, p. 225).

I argue that researching prejudices as source of disvalue entails going beyond prejudice as negative evaluation and implies researching how indignity, degradation, humiliation, come about as outcome of social processes. In liberal democracies the line separating dignity from indignity is extremely precarious. Going beyond prejudice as negative evaluation can reveal the breadth and depth of paradoxes lodged at the heart of the social expression of prejudice in liberal democracies. Social psychologists continue to look for the nature and remedies for prejudice in the psychological makeup of individuals, instead of taking seriously democracies' cultural, societal and moral paradoxes, where progressive and benevolent attitudes mingle with conservative and discriminatory actions, and where sympathy mingles with resentment and contempt (cf. Jackman, 2005). In order to understand the social psychological quandaries of moral inclusion and exclusion of people, one needs to understand the complexities of 
prejudice as harm inflicted by indignity. In turn, understanding the complexities of prejudice as harm inflicted by indignity presupposes understanding the complexities of collective perceptions of people excluded from what Opotow calls "the scope of justice". According to Opotow "those excluded from the scope of justice are seen as: psychologically distant, undeserving of constructive obligations, and eligible for harms that would be unacceptable for those inside the scope of justice." (Opotow, 2011, p. 207). I argue that whatever influences beliefs about excluding people from the scope of justice must be sought in societal-normative arrangements, in "characteristics of society that affect us all" (Becker, 1967, p. 239). These characteristics include a society's creed and form of social organization, social norms, and also elite and everyday assumptions about justice, dignity, decency, fairness and equal treatment of people, welfare, solidarity, etc.

If prejudice hurts and harms people, if it degrades, dehumanizes, alters people's worth, then it should also be studied as a basic problem of collective definition (Tileagă, 2014), that is to say, a basic problem of defining the operative norms, assumptions around what makes possible or hinders common social experience, what French essayist Alain Finkielkraut calls le vivre-ensemble. Collective definitions of common social experience impact on how we define dignity, respect, and worth, of citizens and of people defined as "others"; they impact on the grounds for deciding who is included or excluded from the scope of justice.

Those who are perceived and construed as "distant" or "undeserving" are placed outside the bounds of social sympathy and solidarity. The common-sense and academic view that prejudice and racism are lodged in, and are a reflection, 
of people's (prejudiced) mindsets makes one only half-equipped to contemplate and address the complexities withdrawing social sympathy and solidarity. The idea of prejudice as explicit or implicit "negative evaluation" only partly describes and explains the direction and intensity of prejudices, and uniqueness of targets of prejudice. History, as well as applied research, shows that not all prejudices are the same: they are culturally and ideologically situated, their expression depends on a complex interplay of sociocultural, political and ideological factors. The idea of prejudice as indignity is not just about the forms and consequences of extreme forms of moral exclusion. It is also about understanding of less noticeable, ambivalent, paternalistic, social and ideological ramifications of refusal/denial of dignity as a product of modern democratic society. The explicitly declared European creed of law, justice, security and freedom for all, clashes with concrete practices that exclude, debase, degrade people.

\section{The societal 'life-space’ of prejudice}

The "life-space" of prejudice (Moscovici, 2011) defined as harm inflicted by indignity is societal - that is historical, anthropological/symbolic and sociostructural. Researching the "life-space" of prejudice as indignity presupposes working with and within frameworks that conceive racism and moral exclusion as social and cultural system, firmly lodged at the heart of the current democratic social, political, legal practice. In this section I argue that a social psychology of racism that strives for social justice ought to concentrate its efforts into the development of an alternative, third-way, philosophy that underpins a more radical stance towards researching a society's exclusionary social practices. This 
third-way philosophy refines and complements both the universalist philosophy which portrays racism as universal feature of the human condition as well as the relativist philosophy that emphasizes the nature of racism as sociocommunicative product, and the role of (communal) thinking and argument. This third-way philosophy proposes a viewpoint of how racism operates in society that is not limited to psychology, biology, personality, or social interaction. According to Memmi, racism is the most versatile of social phenomena; it "attacks along many fronts and in many forms, deploying whatever is at hand, and even what is not, inventing when the need arises" (2000, p. 78, emphasis in original).

This third-way philosophy proposes a certain type of exploration, what I call "critical analysis". Critical analysis posits that the answer to the quandaries posed by racism and moral exclusion must be sought in frameworks seeped in a more general and richer theory of society than that offered by contemporary social psychological approaches. Critical analysis is not a version of established approaches to the study of racism like critical discourse analysis (van Dijk, 1993, 2012) or societal psychology (Howarth, 2004). By "critical" I mean the potential of working with and within frameworks that conceive prejudice, racism and discrimination as social and cultural system, firmly lodged in (and influenced by) the historic and current democratic social, political, legal order. Analysis is "critical" in as far as it addresses societal dilemmas, tensions, contradictions, that are "ordinarily invisible" (Opotow, 2011), yet influence how liberal democracies organize themselves and construct their own collective images of sympathy and solidarity.

Contemporary social psychologists call for more "contextualist" 
perspectives in the study of prejudice and racism (Dixon \& Levine, 2012). They argue that the various puzzles and challenges that social psychologists encounter can be approached more profitably by exploring all "heuristic avenues". One way to open and explore available heuristic avenues is to cast the intellectual net beyond the traditional boundaries of the discipline. Critical analysis engages with, and explores heuristic avenues that open a dialogue between social psychology and cognate disciplines. Critical analysis is an attempt to give a more pronounced sociological, anthropological and historical flavor to both universalist and relativist social psychological analyses of prejudice, racism and discrimination. Critical analysis complements universalist and relativist insights with insights from disciplines such as sociology and (moral) anthropology, which have developed conceptual and methodological tools for critically appraising, describing, the societal processes by which societies (democracies) design, promote and justify their own social and ethical orders. A critical analysis of racism takes the form of an integrated, holistic, analysis of society and its presuppositions, including the power (and ability) to offend, degrade, or transform/modify the worth of individuals and communities. A critical analysis of racism takes into account the "life-space" of both extreme and subtler prejudices: their channels of reproduction, their sources and audiences, their composition, as well as their societal expressions and contradictions. The primary aim of a critical analysis of racism is to understand the operative social practices and societal principles that regulate processes of moral inclusion and exclusion, the argumentative spaces they generate, the justificatory rhetoric that accounts for their continuous existence or resistance to them, and potential contradictions between declarations of faith and actual treatment of people. 
Critical analysis rests on three central hermeneutic principles with roots in critical sociology and moral anthropology. The first two are conceptual. The third takes the form of a methodological suggestion.

The first principle refers to how individuals, groups, and communities construct culture, practices, and actions, and act on themselves and others, thus recognizing each other's moral worth (Boltanski and Thévenot, [1991] 2006). Whereas values organize and mediate belief systems that can help one understand how individuals interpret their world, the notion of worth "presupposes a reference to an order whose just character can be revealed: a justifiable order." (Boltanski, 2012, p. 47). Social psychologists and sociologists usually refer to (and attempt to measure) value hierarchies (Schwartz \& Bardi, 2001) and value systems of societies (Inglehart \& Welzel, 2005; Inglehart \& Baker, 2000), whilst ignoring how societies build their own agreement on the worth of people. Inglehart and Welzel (2005) contend that "social values embody a moral imperative ... and are legitimated by dint of the fact that they are shared prescriptions." (p. 442). The democratic order described by these social values is that of self-expression/postmaterialist characteristics of open-mindedness, secularism, rationalism, activism, and achievement orientation (cf. Welzel, 2009). The notion of worth allows researchers to move beyond the analysis of social values, by offering a conceptual scaffold for analyzing democracy in action, the actual processes by which democracies design and promote their own ethical order, and how they go about producing agreements, critiques and justifications of their own social and ethical order.

The worthy are "those who embody the collective, represent the others 
and serve to express the general will." (Boltanski, 2012, p. 15). The unworthy are disruptive of the general will, they lack the strength of affiliation and solidarity that the worthy possess as a matter of fact. Democratic societies define forms of worth that circumscribe specific spheres of (justifiable) justice. Justifications can be linked to descriptions and 'qualities' of people, individual or group traits, institutional frameworks, the 'general will'. Various individual, group and community justifications provide people with different degrees and intensities of worth. What makes a society a democracy is that it is a critical polity, that relies for its existence, on the flexible, provisional, interplay between critique and justification in the private and public sphere, tacitly or explicitly attending to an "order of worths" on the basis of which "the relative worth of the beings present can be established" (Boltanski, 2012, p. 47).

What social psychologists call delegitimization (and, its extreme form, dehumanization), whether described as psychological (Haslam \& Loughnan, 2012; Leyens et al., 2003) or discursive (Tileagă, 2007) phenomenon is, in practice, the process of having one's worth weighed and transformed within societies' moral schemes. Whereas 'normal persons must thus agree to see their own worth vary' (Boltanski, 2012, p. 49), aliens, foreigners, refugees, minorities, must agree to have their own worth modified, or, in extreme cases, taken away from them. The force and impact of social psychologies of delegitimization should stem from exploring closely societies' regimes of worth and justice. Injustice and intolerance are enacted whenever the relative worth of people is not taken into account, and when the existing, legitimate, order or regime of worth in a society offers the premises for the moral exclusion of people without the possibility of retort. 
The second principle is tied to the idea that democracy embodies modes of domination, as well as empowerment/sympathy (Fassin, 2005). Although universal respect for human dignity is one of the fundamental features of democratic society (Misztal, 2012), nation-states create their own cultural politics and policies for dealing with otherness that alter the dignity of people, and vacillate between a desire for order and sympathy, control and pity (Fassin, 2005). According to Taguieff (1987), democracy and community are "regulatory ideas" for how individuals, groups, communities elect to live their lives. But these ideas are not without their contradictions. The task of research is to pinpoint to the nature of these contradictions, and generally, to contradictions "that run through reality" (Boltanski, 2011, p. 110), when trying to understand how these regulatory ideas can be marshaled in the service of intolerance, injustice, social and moral exclusion. One of the crucial aims of a critical analysis of racism and moral exclusion is to be able to describe how social problems/questions are turned into moral questions. There is one primordial way of approaching this question: making visible the taken-for-granted, or as Opotow has suggested, to "reveal what is ordinarily invisible" (2011, p. 219). What is ordinarily invisible is the tension between a society's creed, its humanistic and universalistic ideals, and its exclusionary social practices.

A telling example is that offered by Myrdal ([1944] 1996) in his seminal study of racism in America. Myrdal constructs his argument around the perceived tension between 'the Creed of progress, liberty, equality, and humanitarianism' (vol. I, p. 80) and the reality of segregation. It is this very tension that turned (at least in Myrdal's eyes) a national problem (the 'Negro problem') into a moral problem. The 'American dilemma' of which Myrdal speaks 
of in the title of his book is a moral dilemma, an attempt to reconcile the national conscience reflected in the American creed and the 'reality' of oppression and unequal intergroup relations.

The debate around multiculturalism in European societies points to similar dilemmas. First, how to expand the scope of democracy in order to sidestep what Wieviorka (1998) has called the "tyranny" of both majorities and minorities. Second, how to apply multiculturalism as a general rule and effectively, without "the risk of excluding some groups who could legitimately demand to benefit from it." (p. 901). An added tension at the heart of multiculturalism is that between the universal and the particular. "Not all cultural particularisms", writes Wieviorka, "are necessarily amenable to a multiculturalist policy, or wish to be shaped by it." (p. 901). The failure of management and practice of illegal immigration in Europe is a failure of resolving its inherent tensions. Similarly, the failure of multiculturalism in Europe is a failure of resolving the tensions at the heart of multiculturalism.

In a study conducted in Sweden, Norman (2004) charts the different reactions to the establishment of a refugee camp in the town of Gruvbo, and identifies a similar attitude to that signaled by Fassin, what she calls "ambiguity of solidarity". She notes how "among Gruvbo residents, the whole spectrum of feelings and opinions about refugees was present - from the greatest hostility to a tolerant indifference or a certain compassion" (Norman, 2004, p. 211). Norman points to a contrast between the central precepts of Swedish legislation (equality, with upshots such as fairness and solidarity) and a social reality that is not conform to such ideals. As Norman argues, fairness and solidarity are not a given, they are not guaranteed by abstract values enshrined in the national 
constitution. What matters is how you define people ("genuine" or "bogus" refugees, "economic" migrants, etc.). The definition of different categories of persons invests them with different worth, and turns "solidarity into a contested issue" (p. 224). Similarly, in a study with Finnish Roma activists, Nordberg (2006) identifies a tension between the universalist ideals of the Finnish welfare state and a "sense of exclusion from full citizenship that derives from the same national culture" (p. 536). The exclusion and inequality of which Roma activists talk is the upshot of this tension. It is what we refer routinely to as "national culture" that contains the seeds of both citizenship (inclusion), as well as marginalization (exclusion).

What these examples show is that advanced liberal democracies are mechanisms of domination as well as empowerment. They also show how the tension between empowerment and domination permits societies to "regulate", "police", the public, societal, expression or suppression of racism and moral exclusion. ${ }^{1}$ The familiar tropes of anti-immigration rhetoric, toughness, as well as reasonableness, order and sympathy, are mingled in the discourse of elites and lay members of society. This discourse is a social product of democracies, it belongs to "the cultural schemes of the society (or societies) in which historical action unfolds." (Sahlins, 2004, p. 292).

The third principle is entrenched in the dictum, aptly formulated by Blumer: "respect the nature of the empirical world and organize a methodological stance to reflect that respect" ([1969] 1998, p. 60). A corollary of this is that methods (and concepts) emerge as a concentration on "public affairs", on problems, not for their own sake (Jahoda, 1982; Jahoda et al., 1971). Researching public affairs forces researchers to refrain from building a priori 
models, classifications, etc., of the object under investigation, and work with data generated in and by cultural spheres. One of major consequence of this would be the extension of social psychology's sources of data, not limited to the conventions of positivist and relativist approaches. Data would be a product of practice, not shaped by the social psychologist to suit a particular approach, and created with the aim to make some aspect of social reality more visible, to support a culturally located account of a particular practice or aspect of social reality.

Social psychology of racism and moral exclusion cannot simply concern itself with moral issues in the laboratory or in social interaction. It needs to confront them in what ethnographers and anthropologists call "field situations" and what social action researchers call "field experiments in social change" (Lewin, 1946, p. 36). The aim is to render visible, and clarify, moral issues in their cultural, historical, and practical, contexts. For instance field experiments in prejudice reduction show that it is possible to construct integrated theory "with one eye to the realities of the context and the other to the generalities of theory" (Paluck, 2009, p. 584). In a significant field experiment, Paluck (2009) shows how a reconciliation radio program in Rwanda led to a transformation of listeners' perceptions of social norms. She also notes how research findings emerge not just as a matter of researcher-led design but also out of "the distractions, social interactions, and emotional reactions of a real-world setting" (p. 583).

Respecting the nature of the empirical world (and attending to what it has to offer) suggests that research would proceed and progress incrementally, iteratively, reflexively, through various social, cultural and political "sites", which 
throw into the mix various valuations, positions, ambiguities. The trajectories of research projects would be "mobile" and "multisited", with analytic developments discovered along the way rather than a matter of design (cf. Marcus, 1998). A transformed social psychology of racism needs to be able to resist the temptation of drawing universal conclusions from data, and to allow for open "possibilities" and "unintended consequences" in the research process (Carrithers, 2005). It should also be prepared to "explore questions overtly present but also questions which remain covert or unformulated." (Fassin, 2008, p. 341).

\section{Moral exclusion in Europe: the fate of the Roma}

Social psychologists dealing with racism and its consequences, various forms of inequality and domination (and resistance to domination), human rights violations, etc. would benefit from including critical analysis in their research projects, with the aim to facilitate a deeper understanding of racist and exclusionary practices. The aim of critical analysis is not to supplant existing social psychologies of racism, but refine and broaden them.

Critical analysis opens the way for a meaningful, and transformed social psychology of racism and moral exclusion that can establish itself more as a sociology and anthropology, rather than a psychology, of modern democratic culture. In this section I assess the value of this assertion with reference to the fate of the Roma minority in Western and Eastern Europe.

An "intricate web of labels and attitudes" meets anyone who wishes to understand the Roma (Matras, 2014). For most Europeans, The Roma continue 
to represent the epitome of foreignness. The Roma are perceived as unmeltable ethnic minorities (MacLaughlin, 1998), the inner enemy (Sigona, 2003), the alien next door (Bauman, 1990), they have historically been construed as a "problem" in need of a "solution". For centuries, the Roma were the victims of a special kind of racism, one "which juxtaposes nationalism and colonialism in such a way as to draw clear distinctions (and boundaries) between the 'civilized native' and the 'barbaric other'” (MacLaughlin, 1998, p. 1023). The current European project of accommodating diversity without troubling national sovereignty or unity does not seem to find an appropriate place for Roma's (European) aspirations.

The case of elite and everyday discourse directed at the Roma minority in Western and Eastern Europe is a conspicuous, some would say, prototypical example of what some have called European anti-Gypsyism (Nicolae, 2009) or Romaphobia (Ljujic et al., 2012).2 The criminalization of Roma in Italy (Costi, 2010), Roma killings in Hungary (Tábori, 2009), their frequent evictions, or relocations, in France, the erection of walls separating communities in Slovakia, or the various calls for and cases of sterilization of the Roma in some European countries, are only a few examples of deliberate attempts at removing the Roma minority from the domain of moral acceptability. The descriptions used by ordinary people or declarations of public figures that Roma are the "scum of the earth", "not fit to live among people", or that they "are animals and behave like animals" (Tileagă, 2014) add to an unflattering image of present-day Europe where, with extraordinary regularity, the Roma, are seen as expendable and portrayed as failures in the moral, institutional, motivational schemes of societies.

We are constantly reminded by politicians, journalists, etc., as well as 
social psychologists, that we live in an "age of minorities" (Moscovici and Pérez, 2009). We are also reminded that not all minorities are alike. Roma, as "problem group", is quite a familiar trope in private and public discourse. Characteristics such as their inability to adapt to "civilized" life, their transgression of moral and spatial boundaries, are part of a prevalent diagnosis that presents Roma as deviant and transgressing the moral/civilized boundaries of European societies.

European discourse on the Roma reflects a variety of exclusionary ways of talking about difference and otherness deeply engrained in the discursive texture and social practices of European societies; practices that demean, delegitimize, dehumanize, and yet are not necessarily perceived as racist. Intolerance, as well as tolerance, is grounded in the flexible cultural repertoires and resources, the 'stock' of everyday beliefs about morality, transgression, fairness, justice, etc., that every society bestows its members (Tileagă, 2007; Opotow, 2007). The symbolic role that the "Gypsy", the "Traveller", has played through the ages in European culture, the range of images, representations, emotions, that it evokes in people's minds ensures the relatively stable perpetuation of a racist social imaginary. This racist social imaginary has a discursive and cultural history, and reverberates in each and every country of the European continent (cf. Fraser, 1992 for a comprehensive historical account). Moscovici (2011) shows that the social representation of Roma in Europe is articulated around narratives with long histories that present them as artistic, on one hand, and as criminal, on the other hand. Moscovici argues that the "figurative kernel" of the social representations of Roma/Gypsies is articulated around several core repertoires ("themata"): nomadic/sedentary, clean/dirty, and the taboo of contact. The content of representations of Roma in private and 
public spheres explains the special character of prejudice against them. "The real prejudice" against Roma, Moscovici writes, "focuses on the duality of human/not human, culture/nature and domesticated/wild" (2011, p. 450), and is underpinned by a historical taboo of contact. Experimental research on infrahumanization (e.g. Leyens et al., 2000, 2001; Paladino et al., 2002) and dehumanization (e.g. Giner-Sorolla et al., 2011; Bain et al., 2013) support Moscovici's observation, and confirm a well known anthropological insight, that "population groups ... grant the dignity of a truly human condition only to their own members and place outsiders on an animal level" (Lévi-Strauss, 1992, p. 25).

The various positions taken by European prime ministers, politicians, mayors, commentators, are part of an unfolding argument about the moral status that should be assigned to the Roma. It is an argument that each nation-state (and European society in general) conducts with itself. Some, like the Europarliamentarian George Schopflin, consider that Roma's existence is "absolutely dysfunctional, in total opposition to the tradition of the majority." The mayor of Cholet (western France), Gilles Bourdouleix, defends himself against accusations that he told a group of Roma that "maybe Hitler didn't kill enough of them", whereas the mayor of Nice (southern France), Christian Estrosi, calls for all French mayors to follow his methods (24h surveillance of the Roma), and "not surrender". To the great majority of Europeans the presence of the Roma makes for moral uneasiness. It is tempting to relegate these positions to the "extreme" or to what Taguieff has called "barbarism". Taguieff himself warns of the limitations of positions that relegate racism to "barbarism", as "those destined to barbarism are also products of modern democratic society" (1987, p. 154). 
The form and content of the argument that every society conducts with itself will facilitate the demarcation of "the mild from the strong" (Billig, 2002, p. 181), as well as the cultural and societal parameters for judging, justifying, promoting or defending social inequality/ social justice, tolerance/intolerance. ${ }^{3}$

The language of European institutions, national and European politicians, social activists, ordinary people, is one of collective definition (Blumer, 1971) that is, it constitutes the "reality" of how particular individuals, groups, and societies chooses to 'define' one of its minorities as a social problem that requires a European (read acceptable) "solution". Europeans seem to agree on the existence of a social problem, but they disagree on the moral nature of the social problem.

\section{Moral exclusion and spheres of justice}

The Roma in Europe represent the return of the unruly body, a collective that embodies partial society, whose rules, norms, behaviours, are perceived as transgressive and beyond moral acceptability. The "citizen" of liberal democracies embodies the cultural totality of his/her society. Anything partial is rejected. Liberal democracies are political totalities that do not tolerate partial societies, or "communities that takes themselves as society" (Taguieff, 1987, p. 484). The democratic ideal represented by the nation-state is that of the organic community. On the outskirts of European towns, the Roma construct partial societies, which are then destroyed by civil authorities. In theory, liberal democracies posit that there is not a legitimate basis for a hierarchy of social groups, as they share the same rights in the human condition. In practice, liberal democracies are intolerant to anything (procedures, rules, norms, etc.) that does 
not stand "solid behind a reality that is all of one piece." (Boltanski, 2011, p. 154).

Liberal democracies regulate very carefully the public and private space, delegate and entrust representatives of people with the power to include or exclude. Mayors, ministers, prime ministers, politicians, etc. are the democratic representatives of their local communities. They are the representatives of a state that can "deny freedom in the name of the right that derives from freedom" (Lévi-Strauss, 1992, p. 285). They are the embodiment of the general interest, and sphere of democratic justice that can deny "others" a right of admission, a right of presence within the boundaries of the nation-state. For instance, the prefecture of Veneto (northern Italy) justifies its latest expulsion of Roma by saying that "the Italian authorities reserve the right to expulse European citizens if these have failed to integrate socially and culturally". Beyond Europe, Australia's "stop the boats" policy is a shameful example of how, a country, signatory of the 1951 refugee convention, reserves the right to not admit any refugees on its shores, and, instead, reroute them to 'camps' in the much poorer Papua New Guinea.

Law, justice and security are key values that guide policies that deny people freedom in the name of freedom. These values have a history within the European project. One example is given by Jacques Delors, former President of the European Commission, who connects European values with a description of Europe as an area of "law, justice and security":

Europe does represent an area of law, justice and security... When we speak of an area of law and security we are coming back to our shared values as a feature of Europe, values that ought to restrain us from falling back into humanity's great failings: violence, denial of the other, everyday racism. Europe is the counter to these failings, a huge common asset, and we have to fight every day to preserve it and even to improve it. (Eurozine, 2011). 
Admission (inclusion) and exclusion in Europe stem from conceiving Europe as an area of "law, justice and security", values which permit the creation of "tests" of worth for aliens, refugees, strangers, whose format they are, unfortunately, not able to change (Boltanski and Thévenot, [1991] 2006). The values of law, security and justice generate a social domain where different democratic spheres of justice operate (Walzer, 1984). ${ }^{4}$ In theory, democratic spheres of justice have as their basis the notions of freedom (freedom of speech/expression, freedom of movement) and equality (equality of opportunity, equality before the law), yet, in practice, they sustain a vision of justice that allows for the affirmation of "the territorial state, specifying the rights of its inhabitants and recognizing the collective right of admission and refusal" (Walzer, 1984, p. 44).

The nationals (the citizens) live in the realm of choice - they can choose whom to admit and whom to exclude. The representatives of the community (e.g., mayors) can choose on behalf of the community. They express the supposedly 'general will' of the community. They need to find a justifiable argument for exclusion, for acting upon those deemed 'undesirables'. For instance, the mayor of Baia Mare (a Romanian town in northwestern Romania) justifies erecting a wall separating the Roma community from their neighbours in town as "a step forward towards their civilisation and emancipation". Two years after the wall was erected, despite complaints from Roma groups and civil society activists, its construction is deemed "within the law" by the courts, and, of course, the situation of the Roma behind the wall has not improved.

The 'undesirables', on the other hand, live in the realm of necessity. 
Necessity goes against the original European creed based on 'common interest'. outlined by Jean Monnet, one of the founding fathers of the European Union, in a speech before the European Congress of the German Social-Democratic Party in 1964:

It is no longer a question of maintaining the past: what matters is to transform it, to establish in the world a new and peaceful order based on equality and eliminating the spirit of superiority... This Community is based first and foremost on the common interest. In order that the citizens of our countries may seek, grasp, and sustain the common interest, conditions must be created which will gradually change their attitude and behavior towards each other: from having been national, their problems must become common. This can only be achieved and obtained by means of common laws and institutions.

In theory, all members of the European Union abide by the common laws and institutions of the European Union. In practice, though, the common laws and institutions of the European Union do not offer guarantees against particular, local, decisions of nation-states. The label "European citizen" does not offer much protection to Romanian, Bulgarian, or Slovak Roma traveling and attempting to settle in the Union according to 'freedom of movement' rules. Liberal European democracies are constantly critiqued for their breach of European laws or directives, yet they reserve the sovereign right to admit or evict whomever they see fit. They abide by a practical version of (national) justice, which stipulates that any part of national territory is a common good of the community, and therefore cannot to be used for any unspecified or unexpected purpose.

Self-worth, dignity, which most of us take for granted is refused to Roma. Roma are not only actively degraded by societies; they are also constantly reminded of their modified worth and degraded status. The new, planned, democracy of the EU presents itself as a progressive project of inclusivity, 
fairness, but also firm accountability. Major European think-tanks are tasked with delivering social justice: solving the 'problems' of integration, the negative consequences of poverty, destitution, unemployment, inequalities of health, gender. The situation of the Roma is deplored, but recognized as very difficult to change. It is the urgent goal of these institutions to remove inequality, whilst civilizing, therefore giving priority to eliminating societal ills over ensuring everyday respect for some its more vulnerable members. It is, mistakenly, believed that respect, dignity, will follow as byproduct of the elimination of societal ills. The various pragmatic dimensions of planned social justice are the perfect ground for the perpetuation of exclusionary social practices that lead to indignity and degradation of Roma.

\section{Directions for critical analysis in social psychology of racism and moral exclusion}

The critical project in social psychology of racism is already well underway (Dixon \& Levine, 2012). Taking full advantage of possible interdisciplinary affinities might help boost and open up this project to new possibilities. Social psychology can only turn its trade to the analysis of exclusionary social practices if, at the same time, it is prepared to assimilate, creatively borrow or incorporate, strands of thought from the social sciences, so that a comprehensive view of racism as a cultural phenomenon may gradually evolve.

Some of the most dynamic currents in sociology and anthropology (Boltanski, 2011, 2012; Fassin, 2005, 2008) can reinvigorate and reorient a renewed social psychology of racism. Social psychology is not the only field concerned with social change and social justice, and it is not the only one that is 
concerned with approaching social change and social justice scientifically. Social psychology of racism and moral exclusion can benefit from eschewing conceptual and methodological isolation. Social psychologists have a lot to learn from critical sociologists and moral anthropologists who have been at the forefront of creating frameworks that engage closely with social justice and formulate what remains "unformulated" by individuals and collectivities that live the society of which (and within which) they speak (cf. Fassin, 2008).

Critical analysis proposes social psychological intelligibility of particular lifeworlds, actions, practices, etc., but it requires empirical grounding and conceptual elaboration with the help of kindred fields. As Lewin put it, "psychology, sociology, and cultural anthropology each have begun to realize that without the help of other neither will be able to proceed very far" (Lewin, 1946, p. 36). Social psychology of racism has not always followed or explored closely Lewin's insight. By turning to sociology and anthropology, social psychology of racism can address both the issue of "general laws" that "deal with the relation between possible conditions and possible results" (ibid., p. 36), as well as the issue "diagnosis" of specific situations. As Lewin argued, both types of research objectives are needed in social research. By engaging conceptually and methodologically with critical sociology and moral anthropology a renewed social psychology of racism can move beyond diagnosis of social issues, towards the "proper placement" of research process "within social life" (ibid., p. 37).

Social psychology of racism and moral exclusion faces two major (interrelated) challenges. First, both intolerance and tolerance are aspects of collective life and collective definition. If it is true that racism is "a cultural, social, and historical presupposition" (Memmi, 2000, p. 32), then it needs to be 
studied accordingly. In order to tackle racism and moral exclusion one needs to understand the collective historical and societal conditions that make racism and moral exclusion possible. Second, and perhaps more importantly, it needs to address the narrowness of its methodological choices and data sources. As Condor argues, "from its inception, the social psychology of prejudice embraced modernist fantasies that the systematic application of scientific method could offer utopian solutions to societal problems of social inequality and conflict" (2006, p. 8).

Moreover, the systematic application of the scientific method and the range key findings of psychological research do not offer necessary and sufficient grounds for human rights claims (Kitzinger \& Wilkinson, 2004). The problem is that psychology (psychological sciences) tend to "treat absolute and inalienable human rights as if they were contingent on the psychological experience and capacities of an oppressed group" (Kitzinger \& Wilkinson, 2004, p. 188). ${ }^{5}$

In order to meet and satisfactorily resolve these challenges social psychology of racism and moral exclusion needs to promote critical analyses that can potentially draw, define, create, new spaces of inquiry, within and across cultural contexts and sites. Researching experiences of indignity, humiliation, degradation, in their social, cultural and historical context, describing and critiquing the existing political economies of worth that are the source of prejudices and exclusionary practices in liberal democracies, can offer the foundation for a diversified research agenda. By diversifying its research agenda, social psychology of racism can also strengthen its activism. Social psychology of racism and moral exclusion can borrow profitably from the "circumstantial activism" of some forms of anthropology, "activism quite specific and 
circumstantial to the conditions of doing multisited research itself" (Marcus, 1998).

The demands of the experiment, representative survey or discourse analyses will constrain the researcher to a specific type of research site, limited by certain types of assumptions, types of analyses, ways of drawing inferences, etc. The vast majority of research projects within the field of social psychology of racism and moral exclusion produce contrived data, that is, data that is the outcome of an exchange between researchers and participants, based on following closely already existing assumptions, procedural principles, and disciplinary ethos. Thus, the "reality" of social phenomena (like racism, inequality, power relations) is "frequently limited to the specific narrow section with which they [social scientists] happen to be familiar" (Lewin, 1947a, p. 7). In this context, psychologists tend to grant "existence" only to "units of certain size, or which concern methodologic-technical problems, or conceptual problems" (ibid., p. 7).

Although contrived data can be used for various purposes, it is, arguably, primarily used for generalizing, fact- and theory-building. If racism is a social and cultural creation, then researching it should rely more on using multiple sources of data in public culture (created in and by cultural spheres) as well as ethnographies of social processes and institutions. As Myrdal himself has made it clear in his analysis of American racism, contrived data is "never enough for posing the practical problems concerning what is right, just, desirable and advisable" (p. 1059). One also needs to be able to use as a resource in analysis each society's social theory - its collective assumptions about people's worth, fair treatment of people, entitlement, access to resources, etc. The powerful and 
complex social theories of societies are not a passive container of social and cultural meanings, symbols, discourses. They are a dynamic, continually shifting stock of prejudices, images, ethical principles, regimes of worth, and moral dilemmas, condensing various "popular forms" of racism and moral exclusion that originate in clusters in beliefs, images, with long histories (Moscovici, 2011).

\section{Conclusion}

When social psychologists research racism and moral exclusion they are, arguably, describing universalistic and particularistic presuppositions of modern (democratic) culture. The social psychologist engaged in critical analysis reassembles the anthropologist attempting to uncover the various meaningmaking layers through which society is organized and reproduces itself (Tileagă, 2013).

This chapter has been an attempt to show how social psychologists can broaden their intellectual repertoire. There is a lot of truth in Kitzinger and Wilkinson's assertion: "the problem for us is that when we speak as psychologists, we do not know how to speak in any other way." (Kitzinger \& Wilkinson, 2004, p. 191, emphasis in original). Social psychologists researching social and moral exclusion should strive to move beyond listing the advantages and disadvantages of their own research methods to fostering a dialogue between kindred traditions (see also Opotow, this volume). They should strive to illuminate actions, practices of inclusion and exclusion, in and across different sociocultural contexts; they should study those moral issues and concerns that societies pose to themselves by developing ethnographies of social, cultural and political processes. 
Liberal democracies reflect and reproduce what American anthropologist Marshall Sahlins called a "brave new anthropological world" (2004, p. 149) that parades "subjects" and "subjectivities", "selves" and "identities", "relations", and so on. Social psychologists should be able to engage with this "new anthropological world" and describe how it frames the quandaries that democracies throw at themselves, especially those related to the moral inclusion and exclusion of people.

The problem of European societies is that racism and moral exclusion thrives in liberal democracies, within the framework offered by the nation-state. The problem that European societies have to tackle is not that of an old racism with a new name. European societies have to tackle a deeper issue: to reflect on the ways in which their own social, cultural and political organization leads to, encourages, and perpetuates indignity, the degradation, the humiliation, of specific groups of people.

Contemporary exclusionary and discriminatory practices of liberal democracies do not take the form of "autistic hostility" (Newcomb, 1947), but rather combine a desire for order and compassion couched in a language of respectability. In order to address the nature of this discourse, social psychologists need to work with a theory of society that describes liberal democracy as a mode of dominance as well as sympathy. This conception of democracy is essential to understanding the societal mechanisms of assigning, transforming or altering people's worth and dignity. The primary aim of critical analysis is of a socio-ethnographic nature - to understand "the evaluative principles and practices operating in the social world, the debates they arouse, the processes through which they become implemented, the justifications that 
are given to account for discrepancies observed between what should be and what is actually" (Fassin, 2008, p. 334-335).

In Racism, Albert Memmi was particularly concerned with how a struggle for social justice could define the social and cultural conditions of "our collective social health". These social and cultural conditions are conditions provided by "determinations of a cultural order." (Sahlins, 2004, p. 292). There is no racism or moral exclusion outside of culture. Social psychologists need to take seriously the idea that justice and injustice stem from society's own discourse about itself. European societies are faced with challenges that may differ from the challenges of other societies. A genuine social psychology of social justice should strive to successfully theorize and ground empirically the multifarious ethical, social, cultural, political, conditions of social justice in liberal democratic societies.

The reverse of inequality is not always equality. The reverse of oppression is not always freedom. Society's discourse about itself, its avowed moral creed, its own particular rules of governance, control, etc., will define what inequality, oppression, is, and what its reverse is. Tolerance, as well as intolerance, is sourced in each society's (liberal) social theory, and its foundational contradictions. The ultimate objective for an extended and renewed social psychology of racism and moral exclusion is to offer a critical account of the social, cultural and political world that makes tolerance, as well as intolerance, possible. This involves, first and foremost, a critique of cultural practices of current liberal democracy. Social psychology can, and should, offer the grounds for systematic social and moral critique of society, rather than start and end with the belief "that there is only one program which is directed toward all the good in the world." (Myrdal, [1944] 1996, p. 1061). Quite the contrary, it 
needs to be able to critique vigorously that position.

"The study of prejudice", writes Serge Moscovici, "will never be worthwhile without taking into account its life-space" (Moscovici, 2011, p. 452). As a consequence, one does not need to wage a "war" on racism and moral exclusion; one needs to understand its life-space and how to fight it as social and cultural creation.

\section{Notes}

I would like to thank Phillip Hammack and two anonymous reviewers who have offered very useful suggestions during the drafting of this chapter.

1. 'Policing' the expression or suppression of racism is not only present at a macro-social level; it is also present in the 'delicate choreography of everyday sociability' (Condor, 2006, p. 15). As studies by Condor and colleagues (Condor et al., 2006; Condor and Figgou, 2012) point out, hearably problematic (xenophobic, racist) comments are 'defended' or disclaimed not only by their producers but also by other participants to conversations. Potential and actual charges of prejudice are dealt with dialogically, as conversational partners may attempt to 'deflect' accusations of prejudice on behalf of others.

2. See Crowe (2008) for an overview of the situation of Roma in postcommunist eastern Europe, and Barany (2001) for an history of eastern European Gypsies. For the Nazi persecution of Roma see Kenrick and Puxon (2009). More recent accounts on the fate of Roma in Europe can be 
found in a recent European Union document on Roma integration that charts the multiple discrimination faced by Roma women, the successes and failures of the implementation of education, policing and public health policies that would empower Roma communities (Open Society Institute, 2011).

3. The European media shapes, stimulates, unifies, and, sometimes directs, the conversation that each nation-state in particular, and European society in general, conducts with itself. The arguments about the moral status of the Roma appear in the pages of wide-circulation newspapers, news interviews, or talk shows. With regularity, European media give national and transnational publics reports and commentaries of events where Roma are agents of transgression.

4. Yet, as Walzer argues, "laws and practices differ from one European country to another and are constantly changing; the situation is complex and unstable." (p. 56).

5. In a radical move, Kitzinger and Wilkinson go even further and suggest that "the paradigmatic framework of psychology as an approach to understanding human beings in the world seems fundamentally antithetical to the conceptual framework of human rights." (p. 191). 


\section{References}

Allport, G.W. (1950). Prejudice: a problem in psychological and social causation. Journal of Social Issues, 6, 4-23.

Allport, G.W. (1954). The nature of prejudice. Reading, MA: Addison-Wesley.

Allport, G.W. (1960) Personality and social encounter: selected essays. Boston: Beacon Press.

Augoustinos, M. \& Every, D. (2010). Accusations and denials of racism: Managing moral accountability in public discourse. Discourse \& Society, 21, 251-256.

Bain, P., Vaes, J., \& Leyens, J.P. (2013). Humanness and dehumanization. New York: Psychology Press.

Bauman, Z. (1990). Effacing the face: On the social management of moral proximity. Theory, Culture and Society, 7, 5-38.

Barany, Z. (2001). The east European gypsies: Regime change, marginality, and ethnopolitics. Cambridge University Press.

Billig, M. (1996). Arguing and thinking: a rhetorical approach to social psychology ( $2^{\text {nd }}$ ed.). Cambridge: Cambridge University Press

Billig, M. (2002). Henri Tajfel's 'Cognitive aspects of prejudice' and the psychology of bigotry. British Journal of Social Psychology, 41, 171-188.

Becker, H. (1967). Whose side are we on? Social Problems, 14, 239-247.

Blumer, H (1971). Social problems as collective behavior. Social Problems, 18, 298-306.

Blumer, H. ([1969] 1998). Symbolic interactionism: Perspective and method. Berkeley: University of California Press.

Boltanski, L. (2011). On critique: A sociology of emancipation. Cambridge: Polity 
Press.

Boltanski, L. (2012). Love and justice as competences. Cambridge: Polity Press.

Boltanski, L. \& Thévenot, L. ([1991] 2006) On justification: Economies of worth, trans. Catherine Porter. Princeton: Princeton University Press.

Brown, R. (2010). Prejudice: its social psychology. Oxford: Wiley-Blackwell.

Carrithers, M. (2005). Anthropology as a moral science of possibilities. Current Anthropology, 46, 433-456.

Condor, S. (2006). Public prejudice as collaborative accomplishment: towards a dialogic social psychology of racism. Journal of Community and Applied Social Psychology, 16, 1-18.

Condor, S. \& Figgou , L. ( 2012 ). Rethinking the prejudice problematic: a collaborative cognition approach. In J. Dixon \& M. Levine (eds.) Beyond prejudice: Extending the social psychology of conflict, inequality and social change (pp. 200-22). Cambridge University Press.

Condor, S., Abell, J., Figgou, L., Gibson, S., \& Stevenson, C. (2006). "They're not racist ... ": Prejudice denial, mitigation and suppression in dialogue. British Journal of Social Psychology, 45, 441-62.

Costi, N. (2010). The spectre that haunts Italy: The systematic criminalization of the Roma and the fears of the Heartland. Romani Studies, 20, 105-136.

Crowe, D. (2008). The Roma in post-communist Europe: Questions of ethnic conflict and ethnic peace. Nationalities Papers, 36, 521-552.

Dixon, J. \& Levine, M. (2012). Beyond prejudice: Extending the social psychology of conflict, inequality and social change. Cambridge: Cambridge University Press.

Dovidio, J., Glick, P., \& Rudman, L. (2005) On the nature of prejudice: Fifty years 
after Allport. Malden, MA: Blackwell.

Durrheim, K. (2012). Implicit prejudice in mind and interaction. In Dixon, J. \& Levine, M. (2012). Beyond prejudice: Extending the social psychology of conflict, inequality and social change (pp. 179-199). Cambridge: Cambridge University Press.

Durrheim, K. (2014) Two histories of prejudice. In C. Tileagă \& J. Byford (Eds.) Psychology and history: Interdisciplinary explorations (pp. 205-222). Cambridge: Cambridge University Press.

Edwards, D. (2003) Analysing racial discourse: a view from discursive psychology. In H. van den Berg, H. Houtkoop-Steenstra \& M. Wetherell (Eds.). Analyzing interviews on racial issues: multidisciplinary approaches to interview discourse (pp. 31-48). Cambridge: Cambridge University Press.

Eurozine (2011). In search of Europe: An interview with Jacques Delors. (http://www.eurozine.com/articles/2011-07-01-delors-en.html) (accessed July 2013)

Fassin, D. (2005). Compassion and repression: The moral economy of immigration policies in France. Cultural Anthropology, 20, 362-387.

Fassin, D. (2006). Riots in France and silent anthropologists. Anthropology Today, $22,1-3$.

Fassin, D. (2008). Beyond good and evil? Questioning the anthropological discomfort with morals. Anthropological Theory, 8, 333-344.

Fiske, S. (2002). What we know about bias and intergroup conflict, the problem of the century. Current Directions in Psychological Science, 11, 123-128. Fraser, A. (1992). The Gypsies. Cambridge, MA: Blackwell

Giner-Sorolla, R., Leidner, B., \& Castano, E. (2011) Dehumanization, 
demonization, and morality shifting. In M. A. Hogg \& D. L. Blaylock (eds) Extremism and the psychology of uncertainty. Wiley-Blackwell, Oxford, UK.

Glick, P. \& Fiske, S. (2001). Ambivalent sexism. In M.P. Zanna (ed.) Advances in experimental social psychology (vol. 33). Thousand Oaks, CA: Academic Press.

Haslam, N., \& Loughnan, S. (2012). Prejudice and dehumanization. In J. Dixon \& M. Levine (Eds.), Beyond prejudice: Extending the social psychology of conflict, inequality and social change (pp. 89-104). Cambridge University Press.

Howarth, C. (2004). Re-presentation and resistance in the context of school exclusion: Reasons to be critical. Journal of Community \& Applied Social Psychology, 14, 356-377.

Inglehart, R. \& Baker, W. (2000). Modernization, cultural change, and the persistence of traditional values. American Sociological Review, 65, 19-51.

Inglehart, R. \& Welzel, C. (2005). Modernization, cultural change, and democracy: The human development sequence. Cambridge: Cambridge University Press. Jackman, M. (2005) Rejection or inclusion of outgroups. In Dovidio, J., Glick, P., \& Rudman, L. (2005) On the nature of prejudice: Fifty years after Allport (pp. 89-105). Malden, MA: Blackwell.

Jahoda, M. (1982). Employment and unemployment: A social psychological analysis. Cambridge: Cambridge University Press.

Jahoda, M., Lazarsfeld, P., \& Zeisel, H. (1971) Marienthal: a sociography of an unemployed community. Chicago: Aldine.

Kenrick, D. \& Puxon, G. (2009). Gypsies under the Swastika. Hatfield: University of Hertfordshire Press. 
Kitzinger, C. \& Wilkinson, S. (2004). Social advocacy for equal marriage: The politics of "rights" and the psychology of "mental health". Analyses of Social Issues and Public Policy, 4, 173-194.

Leyens, J. -P., Paladino, P. M., Rodriguez-Torres, R., Vaes, J., Demoulin, S., Rodriguez-Perez, A., et al. (2000). The emotional side of prejudice: The attribution of secondary emotions to ingroups and outgroups. Personality and Social Psychology Review, 4, 186-197.

Leyens, J. -P., Rogriguez-Perez, A., Rodriguez-Torres, R., Gaunt, R., Paladino, M., Vaes, J., et al. (2001). Psychological essentialism and the attribution of uniquely human emotions toingroups and outgroups. European Journal of Social Psychology, 31, 395-411

Leyens, J. -P., Cortes, B., Demoulin, S., Dovidio, J., Fiske, S., Gaunt, R., et al. (2003). Emotional prejudice, essentialism, and nationalism. The 2002 Tajfel Lecture. European Journal of Social Psychology, 33, 703-717.

Lévi-Strauss, C. (1992). The view from afar (trans. by Joachim Neugroschel and Phoebe Hoss). Chicago: University of Chicago Press.

Lewin, K. (1946). Action research and minority problems. Journal of Social Issues, 2, 34-46.

Lewin, K. (1947a). Frontiers in group dynamics: Concept, method and reality in social science; social equilibria and social Change. Human Relations, 1(1), 541.

Lewin, K. (1947b). Frontiers in group dynamics: II. Channels of group life; social planning and action research. Human Relations, 1(2), 143-153.

Ljujic, V., Vedder, P., Dekker, H., \& van Geel, M. (2012). Romaphobia: A unique phenomenon? Romani Studies, 22, 141-152. 
Marcus, G.E. (1998) (ed). Critical anthropology now: Unexpected contexts, shifting constituencies, changing agendas. Santa Fe, New Mexico: School of American Research Press.

Matras, Y. (2014) I met lucky people: The story of the Romani Gypsies. London: Penguin.

MacLaughlin, J. (1998). Racism, ethnicity and multiculturalism in contemporary Europe: a review essay. Political Geography, 17, 1013-1024.

Memmi, A. (2000). Racism (translated and with an introduction by Steve Martinot, and foreword by Kwame Anthony Appiah). Minneapolis: University of Minnesota Press.

Moscovici, S. (1972). Society and theory in social psychology. In J. Israel \& H. Tajfel (Eds.), Context of social psychology: A critical assessment (pp. 17-68). London: Academic Press.

Moscovici, S. (2011). An essay on social representations and ethnic minorities. Social Science Information, 50, 442-461.

Moscovici, S., \& Pérez, J. (2009). A new representation of minorities as victims. In Butera, F. \& Levine, J. (eds) Coping with minority status: Responses to exclusion and inclusion (pp. 82-103). Cambridge: Cambridge University Press.

Misztal, B. (2012). The idea of dignity: its modern significance. European Journal of Social Theory, 16, 101-121.

Mondak, J. (2010). Personality and the foundations of political behavior. New York: Cambridge University Press.

Mondak, J. \& Halperin, K. (2008). A framework for the study of personality and political behavior. British Journal of Political Science, 38, 335-362. 
Myrdal, G. ([1944] 1996). An American dilemma: The Negro problem and modern democracy. New Brunswick: Transaction Publishers.

Newcomb, T. (1947). Autistic hostility and social reality. Human Relations, 1, 6986.

Nicolae, V. (2009) The enemy within: Roma, the media and hate speech. (http://www.eurozine.com/articles/2009-03-20-nicolae-en.html) (accessed July 2013).

Nordberg, C. (2006). Claiming citizenship: Marginalised voices on identity and belonging. Citizenship Studies, 10, 523-539.

Norman, K. (2004). Equality and exclusion: 'Racism' in a Swedish town. Ethnos, $69,204-228$.

Open Society Institute (2011) Beyond rhetoric: Roma integration roadmap for 2020. Budapest: Open Society Roma Initiatives.

Opotow, S. (2007). Commentary: Moral exclusion and torture: The ticking bomb scenario and the slippery ethical slope. Peace and Conflict: Journal of Peace Psychology, 13, 457-461.

Opotow, S. (2011). How this was possible: interpreting the Holocaust. Journal of Social Issues, 67, 205-224.

Opotow (this volume). Dynamics of social justice.

Paladino, P. M., Leyens, J. -P., Rodriguez, R., Rodriguez, A., Gaunt, R., \& Demoulin, S. (2002).Differential association of uniquely and non-uniquely human emotions to the ingroup and the outgroups. Group Processes and Intergroup Relations, 5, 105-117.

Paluck, E. (2009). Reducing intergroup prejudice and conflict using the media: a field experiment in Rwanda. Journal of Personality and Social Psychology, 
96, 574-587.

Reynolds, K. J., Haslam, S. A., \& Turner, J. C. (2012) Social identity, prejudice and social change: Beyond the Allportian problematic . In J. Dixon \& M Levine (eds), Beyond prejudice: Extending the social psychology of conflict, inequality and social change (pp. 48-69). Cambridge: Cambridge University Press.

Sahlins, M. (2004). Apologies to Thucydides: Understanding history as culture and vice versa. Chicago: University of Chicago Press.

Schwartz, S. \& Bardi, A. (2001). Value hierarchies across cultures: Taking a similarities perspective. Journal of Cross Cultural Psychology, 32, 268-290.

Sidanius, J., \& Pratto, F. (1999). Social dominance: An intergroup theory of social hierarchy and oppression. New York: Cambridge University Press.

Sigona, N. (2003). "How can a nomad be a refugee?': Kosovo Roma and labelling policy in Italy'. Sociology, 37, 69-79.

Stenner, K. (2005). The authoritarian dynamic. Cambridge: Cambridge University Press.

Tábori, Z. (2009) Guns, fire and ditches. A report from Tatárszentgyörgy on the Roma killings (http://www.eurozine.com/articles/2009-12-15-taborien.html) (accessed July 2013).

Taguieff, P.-A. (1987). La force du préjugé: essai sur le racisme et ses doubles. Paris: Gallimard.

Tarde, G. (1969/2010) On communication and social influence: selected papers (Edited and with an introduction by Terry N, Clark). Chicago: Chicago University Press.

Tileagă, C. (2005). Accounting for extreme prejudice and legitimating blame in 
talk about the Romanies. Discourse \& Society, 16, 603-624.

Tileagă, C. (2006). Representing the 'other': a discursive analysis of prejudice and moral exclusion in talk about Romanies. Journal of Community and Applied Social Psychology, 16, 19-41.

Tileagă, C. (2007). Ideologies of moral exclusion: a critical discursive reframing of depersonalization, delegitimization and dehumanization. British Journal of Social Psychology, 46, 717-737.

Tileagă, C. (2013). Political psychology: Critical Perspectives. Cambridge: Cambridge University Press.

Tileagă, C. (2014) Prejudice as collective definition: ideology, discourse and moral exclusion. In C. Antaki \& S. Condor (eds.) Rhetoric, ideology and social psychology: Essays in honour of Michael Billig. London: Routledge.

van Dijk, T. A. (1987). Communicating racism: Ethnic prejudice in thought and talk. London: Sage.

van Dijk, T. A. (1993). Elite discourse and racism. Newbury Park, CA: Sage

Walzer, M. (1984). Spheres of justice: A defense of pluralism and equality. Basic Books.

Wieviorka, M. (1998). Is multiculturalism the solution? Ethnic and Racial Studies, $21,881-910$.

Welzel, C. (2009). Individual modernity. In R.J. Dalton \& H-D. Klingemann (Eds.) The Oxford Handbook of Political Behavior (pp. 185-205). New York: Oxford University Press.

Wetherell, M., \& Potter, J. (1992). Mapping the language of racism: Discourse and the legitimation of exploitation. Hemel Hempstead: Harvester Wheatsheaf. 